\title{
Using Concept Maps to Facilitate EAP Speaking
}

\section{Yu Wang \\ Xi'an Jiaotong Liverpool University}

\section{Reference Data:}

Wang, Y. (2020). Using concept maps to facilitate EAP speaking. In P. Clements, A. Krause, \& R. Gentry (Eds.), Teacher efficacy, learner agency. Tokyo: JALT. https://doi.org/10.37546/JALTPCP2019-49

In this paper the author explores the difficulties in EAP (English for academic purposes) speaking and learners' use of concept mapping (CM) as a facilitator to speaking based on a qualitative approach in an international university in China. The introduction and literature review provide an overview of key concepts discussed in this paper including research on teaching EAP speaking, reflective learning, and concept maps. Vocabulary, academic knowledge, and language logic are addressed as the principal difficulties in speaking based on the empirical data from in-depth interviews. Major discussions on the function of CM in speaking learning involve knowledge reflection and consolidation, self-efficacy, and learner autonomy. Instructional suggestions of identified limitations and future research directions are also provided for educators.

本論では、とある中国の国際大学における定性的アプローチを通じて、英語を母国語としない人のEAP(アカデミック目的 の英語) スピーキングの難しさと、スピーキングの進行役としてのコンセプトマップ(CM)の使用について説明する。概要と文 献レビューでは、EAPスピーキングリフレクティブラーニング(内省的学習)、およびコンセプトマップ(CM)の教育に関する研 究を含む、本文で説明されている主要なコンセプトを説明する。綿密なインタビューのデータに基づいて、語䒼、学術的知識. および言語ロジックは、話すことの主な困難さとして取り上げられる。会話学習におけるCMの機能に関する主要な議論には 知識の反映と統合、自己効力感 学習者の自律性が含まれる。また、教育者向けに、CMの使用法、特定されたた制限、および将 来の研究の方向性に関する指導的な提案も提供される。

egarding EFL learners in a monolingual society, speaking, compared with writing and researching skills, has been given insufficient attention especially with the lack of empirical data reporting learners' speaking difficulties (Clennell, 1999; Gan, 2013). However, Richards and Renandya (2002) claimed that developing speaking proficiency is a need and trend for many English language learners worldwide. Impacted by their first languages, learners studying English for academic purposes (EAP) sometimes fail to express themselves in appropriate language with detailed examples and evidence that are usually required in an academic English context. Prior knowledge or experience from their first languages cannot be activated and used in a second language (L2) communicative context due to the lack of efficient knowledge acquisition and consolidation methods (Kaushanskaya, Yoo, \& Marian, 2011; Saville-Troike, 2012). Concept mapping, as a constructivist framework, has positive influences on helping learners make active connections between their prior knowledge, experience, and ideas (Daley, Beman, Morgan, Kennedy, \& Sheriff, 2017). This study was aimed at investigating the correlation between reflective learning and EFL learners' speaking proficiency from empirical research on using concept maps in undergraduate and postgraduate EAP courses conducted at an international university in China.

\section{Literature Review}

Research on EFL and ESL Speaking

Current studies on EFL and ESL speaking are mainly based on linguistic competence and negative emotional effects including lack of confidence and over-anxiety (Biber, 2007;

Gan, 2013; Horwitz, 2008; Littlewood, 2007). On one hand, fluent and accurate speaking means that $\mathrm{L} 2$ learners need to acquire professional knowledge of the target $\mathrm{L} 2$ language system to ensure the explicit production of linguistic knowledge (Gan, 2013). For example, Togatorop (2009) attributed the unsuccessful expression of students to their lack of vocabulary and limited command over grammar in English. Pronunciation, which is affirmed as another influential factor in comprehensible English communication, is regarded as a speaking difficulty for EFL learners in China (Dan, 2006). On the other hand, language scholars and researchers have acknowledged psychological barriers in EFL speaking activities. Horwitz, Horwitz, and Cope (1986) and MacIntyre and Gardner 
(1989) pointed out that nonnative English speakers found themselves more likely to be apprehensive and tense when they were asked to speak in public. Fear of negative peer evaluation and test anxiety are also identified as influential factors causing EFL and ESL speaking anxiety (Horwitz et al., 1986; Tsiplakides \& Keramida, 2009).

\section{Concept Maps}

Concept mapping $(\mathrm{CM})$ has been widely used in education for more than 35 years. For example, CM has been applied in reading comprehension, researching analysis, and writing assistance (Daley \& Torre, 2010; Liu, Chen, \& Chang, 2010; Wette, 2017). It is a cognitive and constructivist learning strategy developed by Novak and Gowin (1984) based on the work of Ausubel (1963). Concept maps (CMs) typically consist of two sectors: a hierarchical structure and propositions between concepts. Novak and Gowin (1984) suggested that effective learning involving logical reasoning helps students build new cognitive structures with prior acquisition and this has been recognized by several researchers (Akinsanya \& Williams, 2004; Hwang, Shi, \& Chu, 2011; Novak, 2010). CMs have been used as visual organizers to document and measure knowledge and cognition structures (Hwang, Wu, \& Chen, 2012; Trundle \& Bell, 2010). Moreover, CM has been used as a tool to cultivate lifelong learning skills, including critical thinking, collaborative learning, and creative working (Budd, 2004; Hanewald, 2012).

\section{Reflective Learning}

Reflective learning, referred to as "learning how to learn" (Brockbank \& McGill, 1998, p. 72) and seen as core to facilitate lifelong learning, is obtaining more attention from researchers, and relevant skills are considered essential for professionals (Colomer, Palliserab, Fullanab, Burrielb, \& Fernándezc, 2013). Reflective learning is basically seen as a reflective process on all sources of knowledge contributing to acquisition and cognition, including active and inactive individual experience (Luckner \& Nadler, 1997, p. 48). Since the 20th century, reflective learning has been introduced and analyzed as an effective learning mode in many countries. According to Kolb (1984, p. 30), reflective learning consists of four processes: concrete experience, reflective observation, abstract conceptualization, and active experimentation. First, learners encounter concrete learning experience by accomplishing some tasks in the real world. Second, following the experience, learners reflect on their actions based on observation. Third, the analysis and conclusion of the previous experience are generated. In the final stage, learners apply what they have gained to new hypotheses in future situations and initiate a new learning cycle. Similarly, Schön (1983) focused on the correlation between thinking and doing, describing reflective practice as "reflection-in-action" (p. 54) and "reflection-on-action" (p. 26), which is seen as an essential component of professional studies. Although reflective learning activities significantly affect teaching in various fields (Mckenna, Yalvac, \& Light, 2009), finding an appropriate method to motivate Chinese EAP learners' learning and improve their academic speaking skills remains to be explored. In this research, concept mapping was used as an implement of reflective learning to investigate the role of reflective learning in solving Chinese EAP learners' speaking difficulties.

\section{Research Questions}

This study was aimed at answering the research questions below:

RQ1. What are the difficulties of nonnative English speakers' EAP speaking in China?

RQ2. How can concept maps facilitate L2 learner's EAP speaking?

Methodology

\section{Participants}

The participants came from an international university where English as a medium of instruction (EMI) is undertaken and almost all the courses are conducted in English.

There were 13 first-year undergraduates (UGs) who took a foundation-level academic English course from September to December 2018 and six 1st-year postgraduates (PGs) who took a postgraduate academic speaking course from February to May 2019. Both courses consisted of 12 teaching weeks with four 100-minute lessons per week for the UG students and two lessons for the PG students. All the participants were native Chinese speakers who had been educated in the Chinese education system for more than 12 years. They were taught by the current author and had first-hand experience of using concept maps for the purpose of EAP speaking improvement. Prior to the initiation of this study, an informed consent form was obtained from the participants and the research was cleared with the university's research ethics committee.

\section{Instrument}

This study was conducted on campus. Qualitative data from in-depth interviews and students' concept maps were used and analyzed. Each interview was about 25 to 30 minutes between one participant and the researcher. Interviews were conducted and recorded in Chinese due to participants' preferences. Then qualitative analysis was performed on the data, including transcription, primary analysis, coding, content analysis, and reporting, which are all in English for publication reasons. 


\section{Interview Questions}

1. What was your biggest problem/concern in academic English speaking before taking the EAP course?

2. What is/was your biggest problem in EAP speaking after taking the EAP course taught by the researcher?

3. What are the causes of the problem you mentioned in EAP speaking?

4. Have CMs helped you in EAP speaking? How?

5. Have CMs helped you with the problem you mentioned in EAP speaking?

6. What are the main advantages and disadvantages of using CMs in class for EAP speaking?

7. Do you have any suggestions to the concept map usage for EAP speaking?

\section{Reason for Choosing In-Depth Interviews}

\section{Small Sample}

All 19 participants are either year-one undergraduate or postgraduate students taught by the researcher herself during the 2018-2019 academic year. The researcher has implemented the usage of $\mathrm{CM}$ for in-class teaching on improving students' academic speaking skills for the purpose of research-led teaching and learning.

\section{Features of Research Questions and Advantages of In-Depth} Interviews

To avoid getting general answers for the two research questions, especially for the first question on speaking difficulty, in-depth interviews offered the opportunity to ask follow-up questions, probe into deeper understanding, and circle back to key questions to produce a richer and more comprehensive analysis of EAP speaking obstacles and CM learning/using experience. Probing \& follow-up questions were used based on participants' responses. For example, if the participant's response for "Have CMs helped you in EAP speaking" were "I am more confident," some follow-up questions would be "How did CMs increase your confidence?" "Can you tell me more about it?" and "Can you give an example?"

\section{Results}

Thematic content analysis has been used for the qualitative data results. First, key words in similar categories have been selected from the interviews as themes. Second, numerical correlations between different themes have been reported by counting the frequency of themes mentioned by the participants.

\section{Research Question 1}

The first research question, which was developed into Interview Questions 1 to 3, was set out to discover the self-recognized difficulties of the EAP learners. The following is a selection of students' responses to Q1 and Q2.

Interview Q1: What was your biggest problem/concern in academic English speaking before taking the EAP course?

The following are some answers from participants:

- "limited vocabulary"

- "cannot find the appropriate words to use"

- "logic problem especially when ideas are in Chinese and need to be translated into English"

- "ideas or speaking cannot be understood by English native speakers because of expression and logic"

- "have little knowledge to respond to academic English speaking questions"

Interview Q2: What was your biggest problem/concern in academic English speaking after taking the EAP course taught by the researcher?

The following are some answers from participants:

- "lack of academic vocabulary"

- "I want to use more difficult vocabulary or language"

- "need to prepare more examples for the topic"

- "preparation is needed before talking"

- "I need more time to think and organize the words" 
Table 1. Learners' Speaking Difficulties Before and After Taking EAP Courses $(N=19)$

\begin{tabular}{lcc}
\hline Speaking difficulties mentioned by participants & $\begin{array}{c}\text { NRs in Q1 } \\
\text { (before) }\end{array}$ & $\begin{array}{c}\text { NRs in Q2 } \\
\text { (after) }\end{array}$ \\
\hline Vocabulary/academic words/general words & 12 & 13 \\
Logic/thinking methods & 11 & 7 \\
Content/knowledge/examples & 6 & 8 \\
Nervousness/confidence & 7 & 4 \\
Grammar/grammatical errors & 5 & 3 \\
Fluency & 4 & 3 \\
Pronunciation/accent & 4 & 2 \\
\hline
\end{tabular}

Note. NRs $=$ number of responses

Table 1 indicates that vocabulary, logic, and content were the top three difficulties for the EAP learners before and after having EAP and CM training. Pronunciation, fluency, and grammar are the least important concerns as speaking barriers. Moreover, the increased number of responses regarding vocabulary and content show that the participants paid more attention to these two issues after finishing the EAP course. It is highly possible that these results were due to participants being exposed to an environment where EAP was required for effortless communication among students in their professional studies. Topic-specific vocabulary, such as terminology, was often used in various academic speaking activities supported by content knowledge. Another reason could be students' experiences with the EAP speaking assessments. The requirements of using topic-related vocabulary and academic examples from textbooks or research were emphasized through the speaking assessment rubrics (see Appendix D) before students' assessments. Students were aware of the fact that using appropriate academic vocabulary and disciplinary knowledge would lead to higher scores in the assessment. However, the number of responses to Q2 about logic, confidence, grammar, fluency, and pronunciation were lower than to Q1. Working as visual organizers to clarify and structure concepts by explicit hierarchies and interconnection (Hwang et al., 2012; Trundle \& Bell, 2010), CMs possibly contribute to developing students' logical thinking and organized speaking performances. Although confidence and fluency are listed as speaking difficulties in Table 1, the probing questions that followed Q1 and Q2 reveal that some causes, such as vocabulary, thinking methods, content knowledge, grammar, and pronunciation, resulted in students' speaking anxieties and nervousness. The practices of CM speaking activities, especially the focus on vocabulary and logic reasoning, may also have alleviated students' concerns about lack of confidence in EAP speaking.

\section{Research Question 2}

The second research question was set to investigate correlations between EAP speaking and $C M$ use. In the interviews, all 19 participants stated that CMs have helped their EAP speaking positively (examples in Appendix A and B). Interview Questions 4 to 7 were designed to provide evidence for this research question.

Interview Q 4 \& 5: How have CMs helped with your academic speaking?

- The following are some answers from participants:

- "help me with enough examples, especially good academic ones learned in class to support my ideas"

- "have more confidence about what I could say, especially before speaking assessment"

- "could speak fluently and confidently in the assessment because I prepared well"

- "Having enough information about one topic will improve my confidence in speaking."

- "After collecting examples from the textbook, I want to have more different and qualified examples and I will search the Internet... I really enjoy this process because I could know more."

- "I enjoy creating mind maps and I will be using it for future studying." 
Table 2. Learners' Beliefs on Benefits of Using CMs in EAP Speaking $(N=19)$

Reasons that CMs facilitate students EAP speaking NRs

Improving confidence 19

Preparing for the speaking assessment/Increasing scores of speaking assessment

Having logical thinking/good logic in English speaking/clear and logical expression

Learning and using vocabulary (academic) effectively

Having more content/rich examples/academic knowledge to the question

Increasing learning/self-learning motivation

Reviewing/memorizing knowledge

Speaking fluently

Note. NRs $=$ number of responses

Table 3. Advantages and Disadvantages of Using CMs in Class for EAP Speaking Based on Question $6(N=19)$

\begin{tabular}{|c|c|c|c|}
\hline Advantages of CM & NRs & Disadvantages of CM use in class & NRs \\
\hline Facilitating speaking & 19 & $\begin{array}{l}\text { Difficult to use CM without } \\
\text { teacher's support }\end{array}$ & 8 \\
\hline $\begin{array}{l}\text { Having interesting CM-related } \\
\text { activities }\end{array}$ & 12 & $\begin{array}{l}\text { Not given enough time for } \\
\text { feedback }\end{array}$ & 5 \\
\hline $\begin{array}{l}\text { Increasing group work and } \\
\text { communication }\end{array}$ & 9 & Time-consuming in making $\mathrm{CMs}$ & 3 \\
\hline
\end{tabular}

Note. NRs $=$ number of responses.

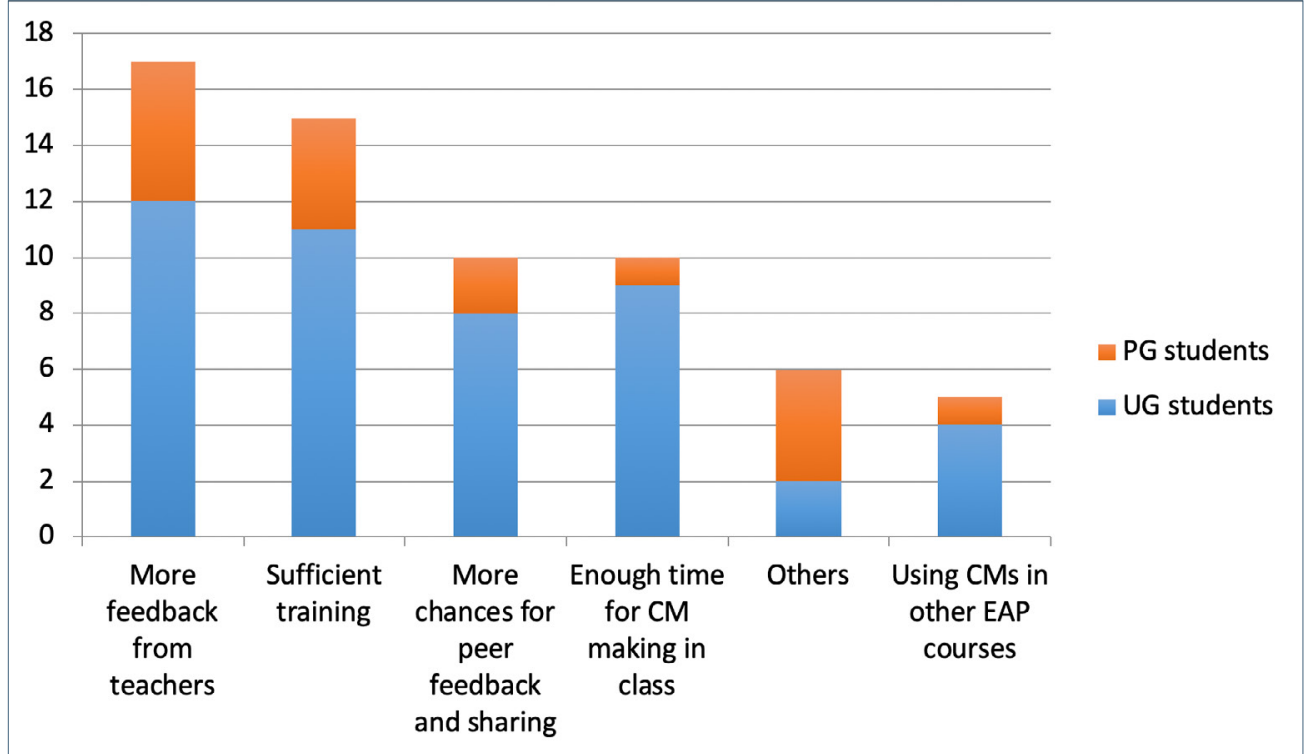

Figure 1. Participants' suggestions of using CMs in EAP speaking based on Question 7. $\mathrm{UG}=$ undergraduate; $\mathrm{PG}=$ postgraduate.

\section{Discussion and Findings}

According to the data, CMs can facilitate EAP learners' speaking in an EMI context. Analysis will be presented in the following three categories.

\section{L2 Knowledge Reflection and Consolidation}

The most obvious advantage of using CMs to facilitate EAP speaking is to help students review and reflect on what they have learned in class and transfer this from short-term memory to long-term memory. All 19 participants recognized this by mentioning "using academic vocabulary," "having reasonable logic in speaking," and "convincing examples/evidence to support answers in speaking" as the most obvious improvements after using CMs. Vocabulary, logic, and content are the top three speaking difficulties for EAP learners, which correlates with how CMs solve students' concerns in academic speaking. Interestingly, grammar and pronunciation, recognized as the important linguistic difficulties for English speaking by many researchers, received little attention 
from the participants. Possible reasons are as follows: First, the English proficiency levels of participants were all at or above the B1 level in the Common European Framework of Reference (CEFR), which was the prerequisite of course registration. Learners at this level usually can use simple language to express opinions without difficulties. Second, communication was promoted primarily based on understanding not accuracy because the majority of speakers on campus are nonnative English speakers.

Based on the interviews, knowledge consolidation had been processed during the fourstep CM-assisted reflective learning cycle (Figure 2) of Review, Reflect, Consolidation, and Lifelong learning, or the two-step cycle of Review and Consolidation. The participants initiated their $\mathrm{CM}$-assisted learning cycle by reviewing knowledge from textbooks, consolidating written knowledge, and acquiring the lifelong capacity to apply flexible CM applications to various disciplines. The missing steps of reflection and lifelong learning (Figure 3) correlate to classroom activities and students' characteristics. First, whether teacher-supported CM activities were arranged could have influenced interviewees' actions on reflection. Though all participants claimed they had experienced self-reflection and peer-evaluation while creating and using CM in class, only seven of them (see Table 2) were motivated to maintain similar reflective processes for use after class. According to interviewees' responses, knowledge reviewing is easier than reflection because students only need to use the semistructured CMs (Appendix C) provided by the teacher to collect and organize information systematically.

Moreover, similar to the active experimentation in Kolb's (1984) experiential learning cycle, the lifelong learning operation of $\mathrm{CM}$ was regarded as an important influence of CM-assisted learning for EAP speaking and was so accredited by seven participants. Based on participants' sharing about after-class CM use, progress has been made regarding business presentations, job interviews, and group presentations for professional studies. Nevertheless, the potential of adapting CM to personal development is more likely to be seen naturally among self-regulated and intrinsically motivated students. For example, students who had the clear targets of language learning and personal development were more willing to spend time on self-evaluation, reflection, and self-exploration on academic studies. Age could have been a factor because the percentage of participants who experienced the full reflective learning cycle in the PG group was higher than that in the UG group. Featured assistance and teaching plans should be considered to promote the full cycle and maximize the possibility of interdisciplinary applications.

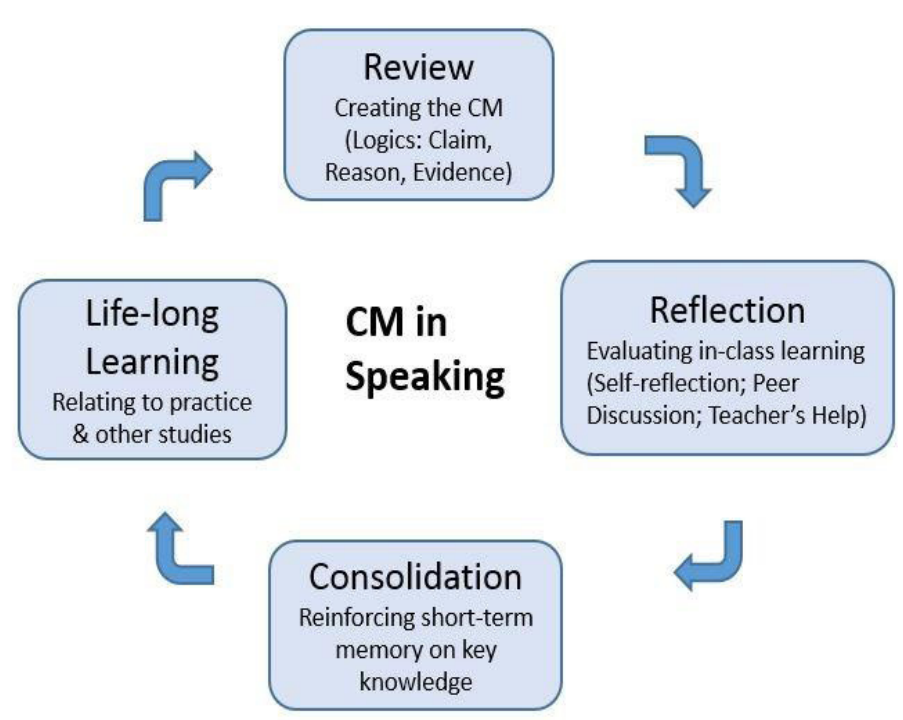

Figure 2. Four-step CM-assisted reflective learning cycle.

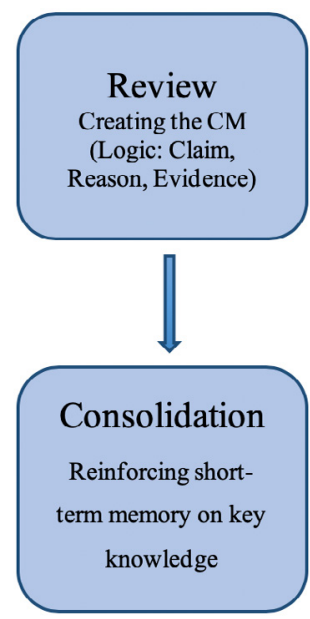

Figure 3. Two-step CM-assisted reflective learning cycle. 


\section{Confidence and Self-Efficacy Building}

Self-efficacy refers to people's expectations on their capacities of execution to produce a specific performance (Bandura, 1994, p.71). According to Bandura (1994), self-efficacy can be summarized into four major sources of influence covering cognition, motivation, affection, and selection: mastery experience, vicarious experience, verbal persuasion, physiological and affective states. As the most influential source of self-efficacy, mastery experience refers to people's perception of successful task fulfillment based on personal accomplishments (Bandura, 1994, p. 71-72).

All 19 participants claimed that the use of $\mathrm{CM}$ contributed to building their confidence. Thirteen students highlighted that $\mathrm{CM}$ played a significant role in preparing their final speaking assessment and the satisfying test performances led to more confidence in EAP speaking. The interviews showed that the majority of the confidence did not come from well-trained speaking skills such as grammatical and linguistic techniques but rather from adequate preparation involving $\mathrm{CM}$ use. Approximately two thirds of the participants expressed that they planned to continue using CMs in the EAP speaking courses due to the benefits they perceived regarding satisfied performances on EAP speaking assessments and academic presentations. The authentic on-campus success, which can be regarded as an example of mastery experience, boosts learners' beliefs on improving academic speaking abilities and motivates them to enact reflective learning via CMs.

Additionally, efficacy-activated processes had more direct and robust influence on 1st-year UG students than PG students. The growing self-satisfaction of in-class speaking activities, such as using CMs for self-introduction and group presentations, generated a positive learning atmosphere by arousing more efficacious learners who would "attribute their failures to insufficient effort" (Bandura, 1994, p. 74) not low ability. Several UG participants emphasized that their speaking performances could be better if they had more time for CMs and less pressure from other courses. Sufficient in-class practice provided UG students more opportunities to obtain formative feedback from their teachers and peers on CMs and speaking performances, which somewhat increased their confidence and self-efficacy in speaking. In addition, the data (see Figure 1) shows that the UG students were more easily motivated by the teacher's direct support such as encouragement and feedback. With little knowledge about EAP, the UG students regarded their teachers as the primary source of not only academic knowledge but also learning methods. When students were asked about their attitude toward CM as a new learning method, most of the UG participants claimed that they had little hesitation in using it in class mainly due to their willingness to follow their teachers' instructions.

\section{Achievements and Suggestions for a CM-Assisted Learning Mode}

Over half of the participants affirmed that the teacher should purposely plan and conduct pre-CM training activities in order for students to benefit from meaningful learning outcomes. For instance, a semistructured CM (see Appendix C) with provision of central concepts, topics, and keywords is necessary for beginners. It works as a guide as well as a model for learners to reflect, review, and relate to their learning experience, which is not limited to EAP courses. The core of this semistructured CM is an instructor who has a holistic view of the learning content, especially the assessment, so that concepts in the $\mathrm{CM}$ are adequately targeted. Another prerequisite for the successful application of CM is a variety of practice. "Interesting in-class activity," "free talking," and "competitive group activities" were mentioned by participants as advantages of using CMs in class. In-class practice should be carefully designed based on students' motivations, English proficiency levels, and previous learning experiences. For example, PG students tend to be more intrinsically motivated, but UG students are more easily driven by extrinsic incentives, such as standardized coursework or assessments. Activities with practical output, including group competitions, poster presentations, and pair work, proved to be positive for both groups. Participants could recognize the significant influence of learner efficacy, such as awareness of achievement, more confidence, and more willingness to be involved.

Receiving effective feedback was desirable for most of the participants, so creating chances for teacher-student and student-student communication on CMs is necessary. It is suggested that extra time should be left for some after-CM activities, such as group sharing and CM analysis. Students with a good knowledge and clear understanding of the logic of $\mathrm{CMs}$ could be given the chance to present their work and inspire others with concrete samples and detailed rationale.

\section{Conclusion}

In this study, the author sought to answer two questions: What are the difficulties of nonnative English speakers' EAP speaking in China and how can concept maps facilitate L2 learner's EAP speaking? The results of the study show that vocabulary, logic, and content were the top three difficulties for the Chinese EAP learners.

The four-step CM-assisted learning cycle is a way for $\mathrm{L} 2$ learners to process written knowledge and transform items from short-term memory into longer-term memory via reflection, consolidation, and interdisciplinary applications. The hierarchical system of connecting concepts with key words and phrases in CMs successfully facilitates 
EAP learners' speaking performances by utilizing topic-related vocabulary, academic examples, logical thinking, and patterns. Other benefits of CM-assisted learning methods for speaking were discovered to be their prominent role in building self-efficacy and promoting autonomous learning. Providing scaffolding for CM users, especially beginners, with a guided map and diversified practices is of foremost importance to attain an effective CM-assisted learning mode.

This action research has also yielded some inspiring implications. First, the results of the research could be tested with a larger, more complex and more varied group of participants, such as several universities in different areas. Second, the collection of data using a mix of qualitative and quantitative methods could ensure the validity and reliability of the findings and enlarge the influence of the study on a larger group of readers from different cultural and academic backgrounds. Third, the research findings have shown that students' motivation is an influential factor in knowledge reflection and self-efficacy.

\section{Bio Data}

Yu Wang has been teaching EAP/ESP for more than 5 years and has taken on the roles of module leader, course developer, and program coordinator for both undergraduate and postgraduate language programs in China. Yu is an active practitioner in conducting pedagogical innovations. Her research interests include speaking anxiety, learner autonomy, and research-led teaching. She is also an accredited fellow from Higher Education Academy and has won awards in Chinese national teaching contests. $<\mathrm{Yu}$ Wang@xjtlu.edu.cn>

\section{References}

Akinsanya, C., \& Williams, M. (2004). Concept mapping for meaningful learning. Nurse Education Today, 24(1), 41-46. https://doi.org/10.1016/S0260-6917(03)00120-5

Ausubel, D. P. (1963). The psychology of meaningful verbal learning. New York, NY: Grune and Stratton.

Bandura, A. (1994). Self-efficacy. In V. S. Ramachandran (Ed.), Encyclopedia of human behavior (Vol 4,pp. 71-81). New York, NY: Academic Press

Biber, D. (2007). Discourse on the move: Using corpus analysis to describe discourse structure. Amsterdam, The Netherlands: John Benjamins.

Brockbank, A., \& McGill, I. (1998). Facilitating reflective learning in higher education. Buckingham, England: Society for Research in Higher Education and Open University Press.
Budd, J. W. (2004). Mind maps as classroom exercise. Journal of Economic Education, 35, 35-46. http://doi.org/10.3200/JECE.35.1.35-46

Clennell, C. (1999). Promoting pragmatic awareness and spoken discourse skills with EAP classes. ELT Journal, 53(2), 83-91. https://doi.org/10.1093/elt/53.2.83

Colomer, J., Palliserab, M., Fullanab, J., Burrielb, M., \& Fernándezc, R. (2013). Reflective learning in higher education: A comparative analysis. Procedia-Social and Behavioral Sciences, 93, 364-370. https://doi.org/10.1016/j.sbspro.2013.09.204

Daley, B. J., Beman, B. B., Morgan, S., Kennedy, L., \& Sheriff, M. (2017). Concept maps: A tool to prepare for high fidelity simulation in nursing. Journal of the Scholarship of Teaching and Learning, 17(4), 17-30. https://doi.org/10.14434/josotl.v17i4.21668

Daley, B. J., \& Torre, D. M. (2010). Concept maps in medical education: An analytical literature review. Medical Education, 44, 440-448. https://doi.org/10.1111/j.1365-2923.2010.03628.x

Dan, C. (2006, June). How can I improve my student's pronunciation? A report submitted to China's Experimental Centre for Educational Action Research in Foreign Languages Teaching. Guyuan, Ningxia, China.

Gan, Z. (2013). Understanding English speaking difficulties: An investigation of two Chinese populations. Journal of Multilingual and Multicultural Development, 34(3), 231-248. https://doi.org /10.1080/01434632.2013.768622

Hanewald, R. (2012). Cultivating lifelong learning skills in undergraduate students through the collaborative creation of digital knowledge maps. Procedia-Social and Behavioral Sciences, 69, 847-853. https://doi.org/10.1016/j.sbspro.2012.12.007

Horwitz, E. K. (2008). Becoming a language teacher: A practical guide to second language learning and teaching. Harlow, England: Pearson Education.

Horwitz, E. K., Horwitz, M. B., \& Cope, J. A. (1986). Foreign language classroom anxiety. The Modern Language Journal, 70(2), 125-132. https://doi.org/10.1111/j.1540-4781.1986.tb05256.x

Hwang, G.--., Shi, Y.-R., \& Chu, H.-C. (2011). A concept map approach to developing collaborative Mindtools for context-aware ubiquitous learning. British Journal of Educational Technology, 42(5), 778-789. https://doi.org/10.1111/j.1467-8535.2010.01102.x

Hwang, G.-J., Wu, P.-H., \& Chen, C.-C. (2012). An online game approach for improving students' learning performance in web-based problem-solving activities. Computers \& Education, 59(4), 1246-1256. https://doi.org/10.1016/j.compedu.2012.05.009

Kaushanskaya, M., Yoo, J., \& Marian, V. (2011). The effect of second-language experience on nativelanguage processing. Vigo International Journal of Applied Linguistics, 8, 54-77. Kolb, D. A. (1984). Experiential learning: Experience as the source of learning and development (Vol. 1). Englewood Cliffs, NJ: Prentice-Hall. 
Liu, P.-L., Chen, C.--., \& Chang, Y.-J. (2010). Effects of a computer-assisted concept mapping learning strategy on EFL college students' English reading comprehension. Computers \& Education, 54(2), 436-445. https://doi.org/10.1016/j.compedu.2009.08.027

Luckner, J. L., \& Nadler, R. S. (1997). Processing the experience: Strategies to enhance and generalize learning (2nd ed.). Dubuque, IA: Kendall Hunt Publishing.

MacIntyre, P. D., \& Gardner, R. C. (1989). Anxiety and second-language learning:

Toward a theoretical clarification. Language Learning, 39(2), 251-275. https://doi.

org/10.1111/j.1467-1770.1989.tb00423.x

McKenna, A., Yalvac, B., \& Light, G. J. (2009). The role of collaborative reflection on shaping engineering faculty teaching approaches. Journal of Engineering Education, 98(1), 17-26. https:// doi.org/10.1002/j.2168-9830.2009.tb01002.x

Novak, J. D. (2010). Learning, creating, and using knowledge: Concept maps as facilitative tools in schools and corporations. Journal of e-Learning and Knowledge Society, 6(3), 21-30. Retrieved from http://www.je-lks.org

Novak, J. D., \& Gowin, D. B. (1984). Learning how to learn. New York, NY: Cambridge University Press.

Richards, J. C., \& Renandya, W. A. (2002). Methodology in language teaching. Cambridge, England: Cambridge University Press.

Saville-Troike, M. (2012). Introducing second language acquisition. Cambridge, England: Cambridge University Press.

Schön, D. A. (1983). The reflective practitioner: How professionals think in action. New York, NY: Basic Books.

Togatorop, E. (2009). Students' obstacles in practicing speaking: A case study at Batam Polytechnic (Unpublished S2 thesis). Universitas Pendidikan, Indonesia.

Trundle, K. C., \& Bell, R. L. (2010). The use of a computer simulation to promote conceptual change: A quasi-experimental study. Computers \& Education, 54(4), 1078-1088. https://doi. org/10.1016/j.compedu.2009.10.012

Tsiplakides, I., \& Keramida, A. (2009). Helping students overcome foreign language speaking anxiety in the English classroom: Theoretical issues and practical recommendations. International Education Studies, 2(4), 39-44. http://doi.org/10.5539/ies.v2n4p39

Wette, R. (2017). Using mind maps to reveal and develop genre knowledge in a graduate writing course. Journal of Second Language Writing, 38, 58-71. https://doi.org/10.1016/j.jslw.2017.09.005
Appendix A

Y1 UG Students' CM Examples in Semester 1, Academic Year 20182019

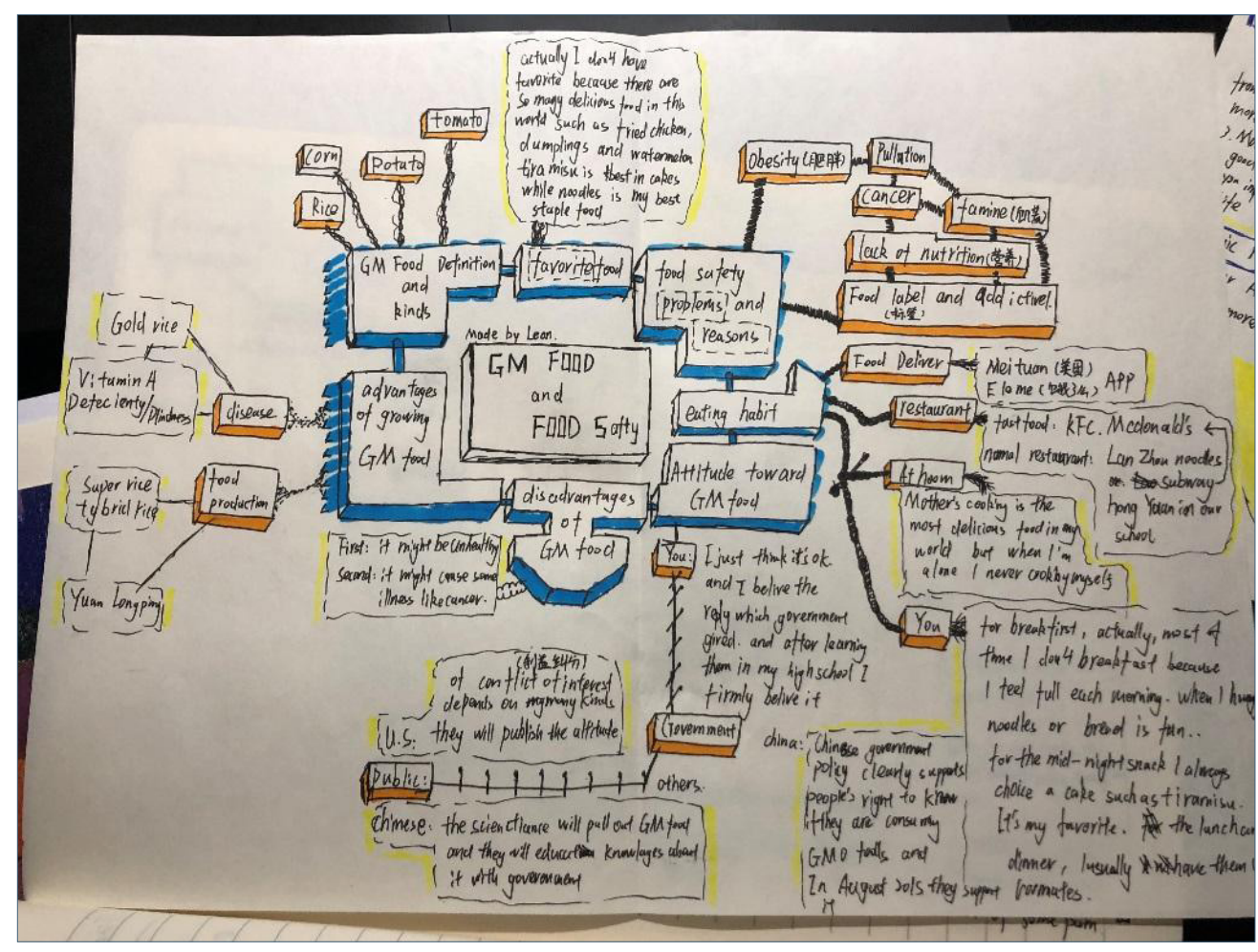




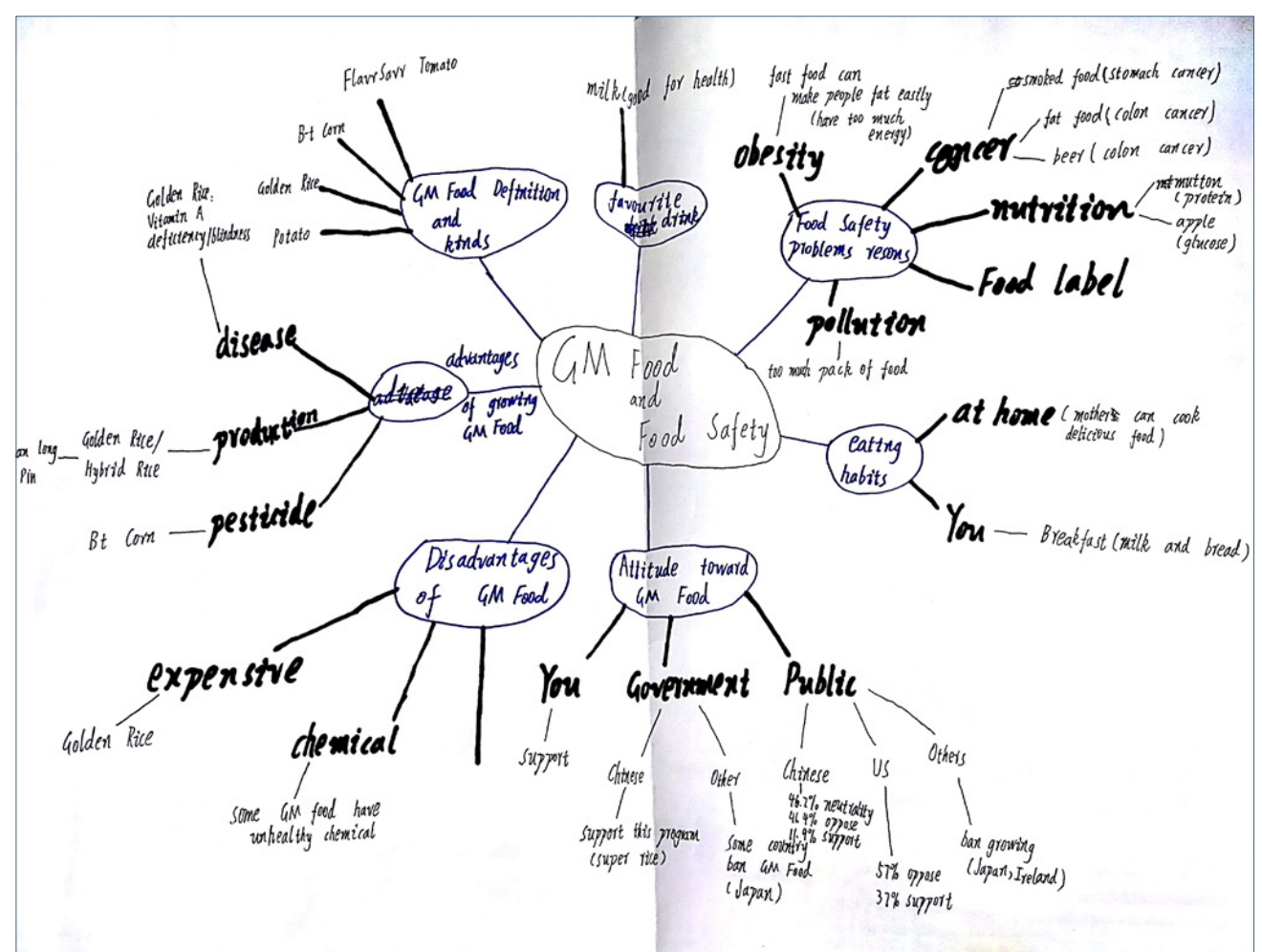

\section{Appendix B}

Y1 PG Students' CM Examples in Semester 2, Academic Year 20182019

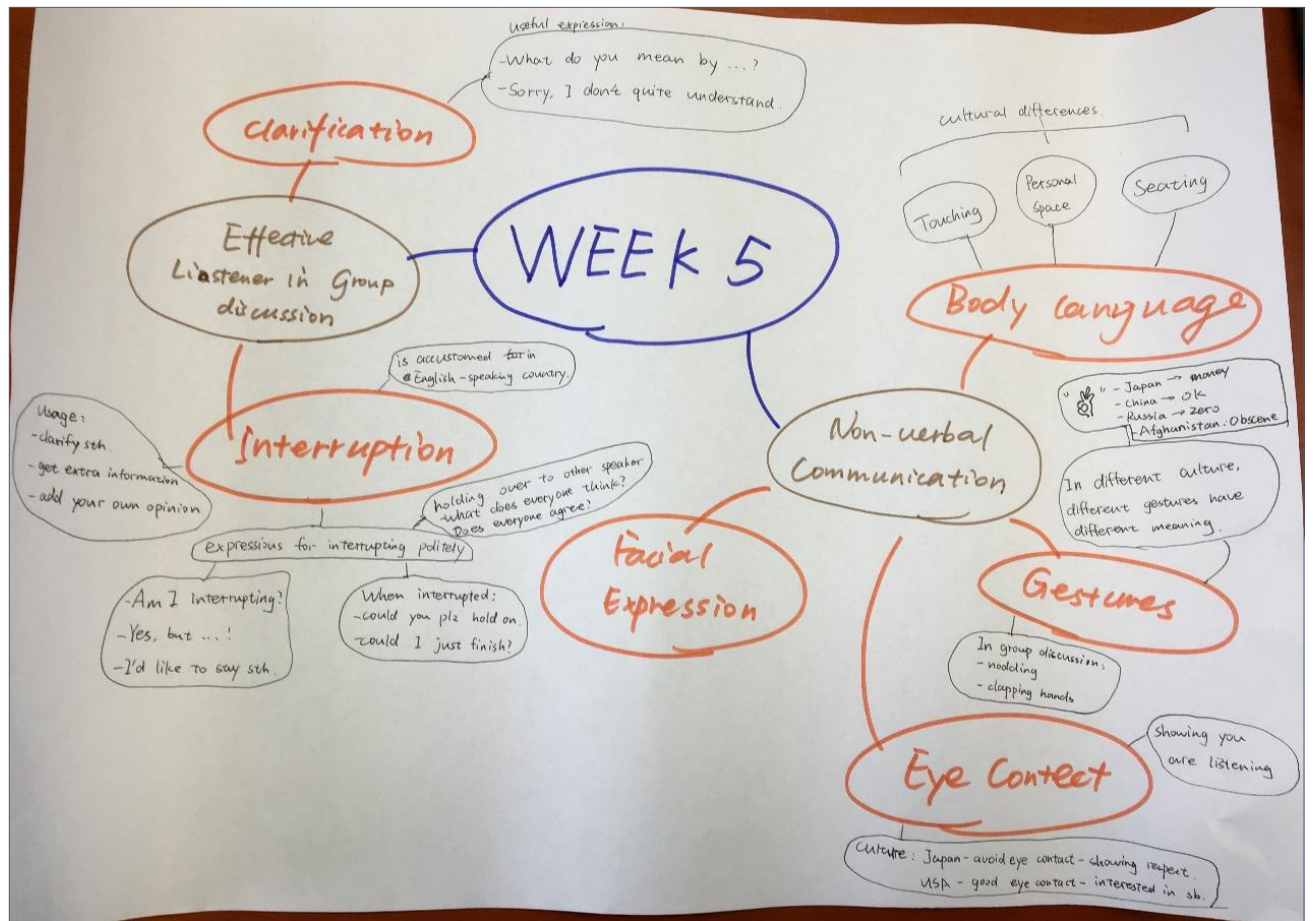




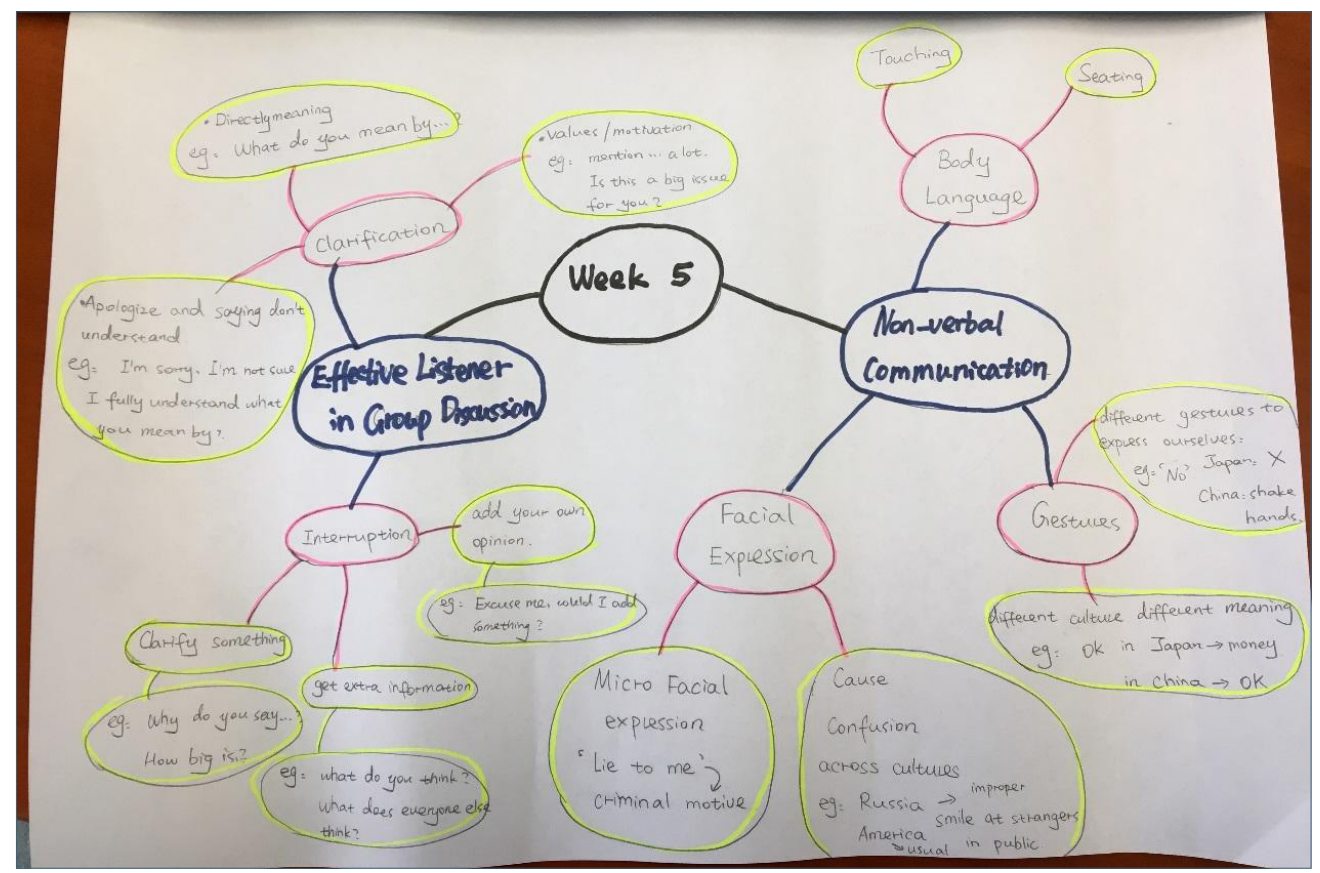

\section{Appendix C}

Semistructured CM Samples Provided by the Teacher From PG Academic English Speaking Course for Students

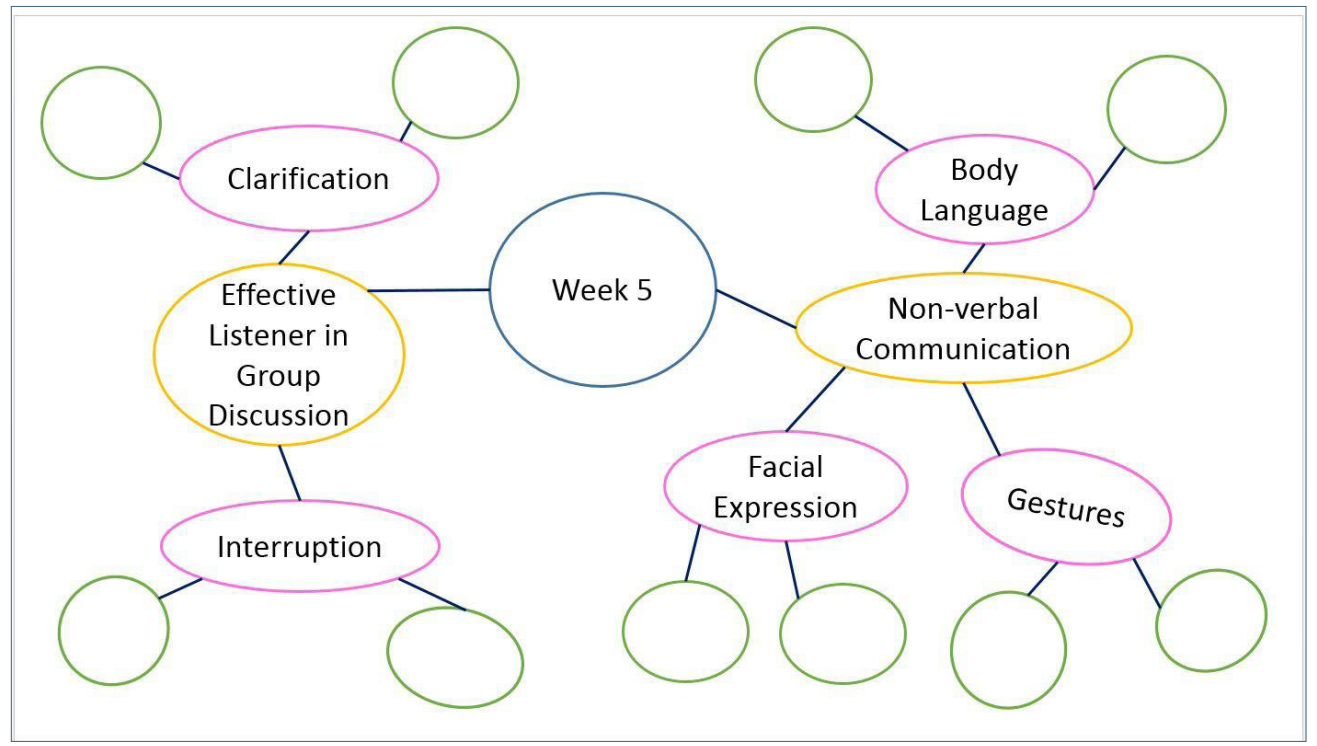




\section{Appendix D}

Speaking Assessment Rubric for PG and UG Foundation-Level EAP Courses LAN906 (PG EAP Speaking Course) Group Discussion Descriptor

\begin{tabular}{|c|c|c|c|c|c|}
\hline \multicolumn{2}{|r|}{ Fluency and Pronunciation } & \multicolumn{2}{|r|}{ Vocab and Grammar } & \multicolumn{2}{|r|}{ Organisation and Interaction } \\
\hline $\begin{array}{c}\mathrm{A} 1 \square \\
5 \%\end{array}$ & $\begin{array}{l}\text { Generally able to maintain fluency } \\
\text { (rhythm and pace) with hesitations } \\
\text { and/or repetitions throughout re- } \\
\text { sponse. }\end{array}$ & $\begin{array}{c}\mathrm{A} 1 \square \\
5 \%\end{array}$ & $\begin{array}{l}\text { A good range of general and } \\
\text { task-relevant vocabulary, though } \\
\text { there may be several lexical errors. }\end{array}$ & $\begin{array}{c}\mathrm{A} 1 \square \\
5 \%\end{array}$ & $\begin{array}{l}\text { Development of main idea(s) is sup- } \\
\text { ported mostly convincing and logical, } \\
\text { but lacks detail(s) and example(s) }\end{array}$ \\
\hline $\begin{array}{l}\text { A2 } \square \\
10 \%\end{array}$ & $\begin{array}{l}\text { Able to maintain high degree of } \\
\text { fluency (rhythm and pace). Unnatural } \\
\text { hesitations and/or repetition are rare }\end{array}$ & $\begin{array}{c}\mathrm{A} 2 \square \\
10 \%\end{array}$ & $\begin{array}{l}\text { A wide range of general and sub- } \\
\text { ject-specific vocabulary, though there } \\
\text { may be a few lexical errors }\end{array}$ & $\begin{array}{c}\mathrm{A} 2 \square \\
10 \%\end{array}$ & $\begin{array}{l}\text { Development of main idea(s) is consis- } \\
\text { tently relevant and logical with some } \\
\text { analysis, including detail(s) and exam- } \\
\text { ple(s). }\end{array}$ \\
\hline $\begin{array}{l}\text { A3 } \square \\
15 \%\end{array}$ & $\begin{array}{l}\text { Maintains full fluency (Rhythm and } \\
\text { pace) with deliberate pauses to show } \\
\text { shades of meaning }\end{array}$ & $\begin{aligned} & A 3 \square \\
& 15 \%\end{aligned}$ & $\begin{array}{l}\text { Extensive range of subject-specif- } \\
\text { ic vocabulary used naturally and } \\
\text { flexibly, though there may be rare } \\
\text { lexical errors }\end{array}$ & $\begin{array}{c}\text { A3 } \square \\
15 \%\end{array}$ & $\begin{array}{l}\text { Competent understanding of the topic } \\
\text { including academic examples. }\end{array}$ \\
\hline $\begin{array}{c}\text { B1 } \\
5 \%\end{array}$ & $\begin{array}{l}\text { Mostly clear pronunciation without } \\
\text { undue strain to listener }\end{array}$ & $\begin{array}{l}\text { B1 } \square \\
5 \%\end{array}$ & $\begin{array}{l}\text { A good range of grammar with suf- } \\
\text { ficient accuracy to convey meaning } \\
\text { with some precision. }\end{array}$ & $\begin{array}{c}\text { B1 } \\
5 \%\end{array}$ & $\begin{array}{l}\text { Can respond to other speakers when } \\
\text { asked, but rarely shows spontaneity in } \\
\text { speaking }\end{array}$ \\
\hline $\begin{array}{l}\text { B2 } \square \\
10 \%\end{array}$ & $\begin{array}{l}\text { Clear pronunciation throughout the } \\
\text { response, including some use of intona- } \\
\text { tion / stress }\end{array}$ & $\begin{array}{l}\text { B2 } \square \\
10 \%\end{array}$ & $\begin{array}{l}\text { A wide range of grammar with } \\
\text { sufficient accuracy to convey precise } \\
\text { meaning; error free sentences are } \\
\text { frequent }\end{array}$ & $\begin{array}{c}B 2 \square \\
10 \%\end{array}$ & $\begin{array}{l}\text { Can respond to other speakers with } \\
\text { spontaneity, showing ability to guide } \\
\text { the discussion. }\end{array}$ \\
\hline $\begin{array}{l}\text { B3 } \square \\
15 \%\end{array}$ & $\begin{array}{l}\text { Clear pronunciation with effective use } \\
\text { of intonation / stress }\end{array}$ & $\begin{array}{l}\text { B3 } \square \\
15 \%\end{array}$ & $\begin{array}{l}\text { Extensive range of grammar pre- } \\
\text { cisely, naturally and flexibly used; } \\
\text { errors are rare }\end{array}$ & $\begin{array}{l}\text { B3 } \square \\
15 \%\end{array}$ & $\begin{array}{l}\text { Maintains and develops interaction } \\
\text { including appropriate responses, eye } \\
\text { contact and body language. }\end{array}$ \\
\hline \multicolumn{4}{|c|}{$\begin{array}{c}\text { Marking guide }=\text { choose level } 1,2, \text { or } 3 \text { for each criterion } \\
\text { Highest possible marks }=100 \% \\
\text { Students need to get at least } 50 \% \text { to pass. }\end{array}$} & $\begin{array}{l}\mathrm{C} 1 \square \\
5 \% \\
\mathrm{C} 2 \square \\
10 \%\end{array}$ & $\begin{array}{l}\text { Uses some simple language for giving } \\
\text { opinions and responding to other's } \\
\text { ideas } \\
\text { Uses a variety of language for giving } \\
\text { opinion and addressing other's points }\end{array}$ \\
\hline
\end{tabular}




\section{EAP023 (UG Foundation-Level EAP Course) Speaking Assessment Rubric}

\section{8-19 Y1S1 SPEAKING DESCRIPTOR}

Task

\begin{tabular}{|c|c|c|c|c|c|c|}
\hline \multirow{2}{*}{$\begin{array}{l}\text { Core tasks } \\
\text { met }\end{array}$} & $\mathrm{A} \square$ & \multicolumn{5}{|c|}{ The student met all core task requirements. } \\
\hline & & Delivery & & Vocabulary and Grammar & & Organization and Development of Ideas \\
\hline $\begin{array}{l}\text { Core } \\
\text { Features }\end{array}$ & $\begin{array}{l}\text { A口 } \\
5 \%\end{array}$ & $\begin{array}{l}\text { - Most pronunciation can generally be } \\
\text { understood, though } L 1 \text { accent has an } \\
\text { obvious influence on stress and intonation. }\end{array}$ & $\begin{array}{l}A \square \\
5 \%\end{array}$ & $\begin{array}{l}\text { - Adequate general and task-relevant vocabulary to } \\
\text { talk about familiar topics. }\end{array}$ & \begin{tabular}{l|}
$A \square$ \\
$5 \%$
\end{tabular} & $\begin{array}{l}\text { - Some development of main idea(s), including the use of } \\
\text { detail(s) and/or example(s). }\end{array}$ \\
\hline $\begin{array}{l}\text { (CEFR } \\
\text { High B1) }\end{array}$ & $\begin{array}{l}B \square \\
5 \%\end{array}$ & $\begin{array}{l}\text { - Is generally able to keep speaking in spite } \\
\text { of some pauses, false starts and } \\
\text { corrections. }\end{array}$ & $\begin{array}{l}B \text { ㅁ } \\
5 \%\end{array}$ & $\begin{array}{l}\text { - Grammatical accuracy generally adequate for } \\
\text { effective communication, though some errors may } \\
\text { obscure meaning. }\end{array}$ & $\begin{array}{l}B \square \\
5 \%\end{array}$ & $\begin{array}{l}\text { - Can use a basic range of discourse markers and functiona } \\
\text { language mostly appropriately for task. Can respond to } \\
\text { other speakers mostly appropriately on familiar topics } \\
\text { (when applicable). }\end{array}$ \\
\hline
\end{tabular}

\begin{tabular}{|c|c|c|c|c|c|c|}
\hline $\begin{array}{l}\text { Advanced } \\
\text { Features } \\
\text { (CEFR low } \\
\text { B2) }\end{array}$ & $\begin{array}{l}D \\
5 \%\end{array}$ & $\begin{array}{l}\text { - Sufficiently clear pronunciation and use of } \\
\text { occasional stress/intonation for clarity. L1 } \\
\text { accent has minor effect on intelligibility. } \\
\text { - Able to maintain fluency (rhythm and pace) } \\
\text { over majority of response with some } \\
\text { occasional hesitations and/or repetition. }\end{array}$ & $\begin{array}{l}D 0 \\
5 \%\end{array}$ & $\begin{array}{l}\text { - A range of general and task-relevant vocabulary, } \\
\text { though there may be some lexical errors. } \\
\text { - Grammatical accuracy adequate for clear } \\
\text { communication (errors rarely confuse or obscure } \\
\text { meaning). }\end{array}$ & $\begin{array}{l}D \square \\
5 \%\end{array}$ & $\begin{array}{l}\text { - Development of main idea(s) is adequately relevant and } \\
\text { logical and includes detail(s) and/or example(s). } \\
\text { - Uses a limited range of discourse markers and functional } \\
\text { language mostly appropriately. Can respond relevantly to } \\
\text { other speakers within the topic (when applicable). }\end{array}$ \\
\hline \begin{tabular}{|l|} 
Exceptional \\
Features
\end{tabular} & $\begin{array}{l}\mathrm{E} \square \\
5 \%\end{array}$ & $\begin{array}{l}\text { - Mostly clear pronunciation using } \\
\text { stress/intonation for clarity throughout } \\
\text { much of response. L1 accent has little } \\
\text { effect on intelligibility. }\end{array}$ & $\begin{array}{l}\mathrm{Eq} \\
5 \%\end{array}$ & $\begin{array}{l}\text { - A good range of general and task-relevant } \\
\text { vocabulary, though there may be some lexical } \\
\text { errors. }\end{array}$ & $\begin{array}{l}\mathrm{Eq} \\
5 \%\end{array}$ & $\begin{array}{l}\text { - Development of main idea(s) is supported mostly } \\
\text { convincingly and logically with some detail(s) and } \\
\text { example(s). }\end{array}$ \\
\hline $\begin{array}{l}\text { (CEFR } \\
\text { High B2) }\end{array}$ & $\begin{array}{l}F \text { 口 } \\
5 \%\end{array}$ & $\begin{array}{l}\text { - Able to maintain fluency (rhythm and pace) } \\
\text { with few unnatural hesitations and/or } \\
\text { repetition throughout response. }\end{array}$ & $\begin{array}{l}F \square \\
5 \%\end{array}$ & $\begin{array}{l}\text { - A good range of grammar with sufficient accuracy } \\
\text { to convey meaning with some precision. A few } \\
\text { systematic errors may persist. }\end{array}$ & $\begin{array}{l}F \square \\
5 \%\end{array}$ & $\begin{array}{l}\text { - Uses a good range of discourse markers and functional } \\
\text { language mostly appropriately. Can respond to other } \\
\text { speakers with spontaneity, showing some ability to guide } \\
\text { the discussion (when applicable). }\end{array}$ \\
\hline
\end{tabular}

a) Students need to achieve Task A (10\%) in order to receive any credit for Advanced or Exceptional features across all categories

b) Students need to achieve all Core Features within an individual category in order to receive credit for Advanced and Exceptional Features in the same category

c) It is always necessary to indicate any Advanced and Exceptional features a student demonstrates, even though they may not receive credit for them due to either a) or b) above. These will be used for feedback purposes.

- A grade of $40 \%$ is equivalent to a High B1 CEFR level.

MFRONT PAGE $\quad$ \&REVIOUS PAGE NEXT PAGE $>\quad$ ONLINE $\quad$ FULL SCREEN

